\title{
Present status of portfolio based training and assessment in postgraduate residency program in Bangabandhu Sheikh Mujib Medical University (BSMMU): A quantitative approach
}

\section{Dr. Bijoy Kumer Paul, ${ }^{1}$ Dr. Sajuti Sarkar, ${ }^{2}$}

\begin{abstract}
Since 2009, the portfolio has been a prerequisite for the evaluation of postgraduate residency programs at BSMMU. This descriptive cross-sectional study was conducted with the aim of investigating the current status of portfolio-based training and assessment in BSMMU`s postgraduate training program. Total 264 residents and 30 faculty members selected conveniently and completed the Likert scale-based questionnaire. A checklist was used for reviewing portfolios $(n=33)$ those were preserved by residents. Study revealed that most of the respondents were male $(68.6 \%$ of residents and $93.3 \%$ of faculty members). About $60 \%$ of residents have given positive views on presence of instruction and purpose about maintaining the portfolio. Several participants expressed concerns because the portfolio content is self-reported; it may include bias or inaccuracy. Regarding opinions of respondents on characteristics of portfolio, both of the respondents perceived high satisfaction on portfolio based learning, reasonable contents, and practicable and feasible use of portfolio $(\mathrm{p}<0.05)$ except regular updating $(\mathrm{p}<0.05)$ and comprehensiveness of portfolio. In line with ownership and motivation, faculty members (4.03) highly assumed that the portfolio completed by residents as requirement of the university than residents (3.22) and $\mathrm{p}<0.05)$. Residents did not agree that they worked on the portfolio during university deadline (2.89) whereas faculty members ((3.73) showed vary positive views in this regard. Concerning commitments to use the portfolio, both respondents have conveyed high expression (mean >3.5) on the relationship between residents and supervisors so the role of an available supervisor in direct observations of the residents and dedicated educational meetings, giving feedback and support, cannot be exaggerated. Relating to assessment of portfolio, overall views of the respondents have expressed poor to moderate views and faculty members ( 2.37 to 4.23 ) have less satisfaction than residents ( 2.88 to 3.73 ). Though there are so many constraints such as the lack of clear purposes and instructions, poor understanding regarding ownership, assessment issues, and confusion about educational impact in future, but the portfolio as a feasible and acceptable tool to train and assess clinical competence and clinical specialization. Study recommended for generic format of portfolio based training and assessment to be considered in Bangladesh context. All Stakeholders should be well oriented at the beginning for utilizing the portfolio (supervision, monitoring and assessment system).
\end{abstract}

\section{Key words: Portfolio. Assessment, Training, Residency program}

1. Associate Professor, Department of Public Health \& Informatics Bangabandhu Sheikh Mujib Medical University Shahbag, Dhaka.

2. Assistant Professor, Department of Biochemistry, Mymensingh Medical College.

Address of correspondence: Dr. Bijoy Kumer Paul, Associate Professor, Department of Public Health \& Informatics, Bangabandhu Sheikh Mujib Medical University, Shahbag, Dhaka.

E mail: paulbijoy29@gmail.com

\section{Introduction:}

Medical education is a continuum from undergraduate through internship to Bangladesh Journal of Medical Education 2022; 13(1); Paul et al., publisher and licensee Association for Medical Education. This is an Open Access article which permits unrestricted non-commercial use, provided the original work is properly cited. postgraduate medical training, which is further divided into two stages: basic and higher professional training. Nowadays the 
rapid changes in science and technological development have affected the training systems. Global educational reflection and assessment by health professionals has shifted towards a focus on competence in real-life situations (Taber et al. 2010). Learning and assessment in the workplace is based on the theory of adult learning, which is primarily experiential, with the Kolb learning cycle describing how a learner develops by observing lived experience, reflecting to this experience, making plans to apply this learning and making plans to create a new experiences (Kolb DA, Boyatzis, and Mainemelis, 2001). ${ }^{2}$

In 1990 GE Miller distinguishes four levels at which students got to be evaluated: "knows" - factual review of information; "knows how" - application of information; "shows how"- a mimicked examination circumstance where competence is evaluated; and "does" - assessment of execution in a real-life settings. Portfolios supply an evaluation framework that has the manageable to assess the candidate at the stage of "does."

In 1999 Harden et al. portrayed three sorts of learning outcomes within the wellbeing professions: those that relate to the "tasks" of the wellbeing professional, or what the wellbeing professional does in her or his dayto-day exercises; those that relate to the approach or attitude that the wellbeing proficient takes to those "tasks"; and those that relate to the professionalism of the person. The quality of portfolios lies in their capacity to assess results related to attitudes and professionalism.
In practical terms, a student's portfolio for assessment purposes may be a combination of reports, papers, and other elements that match the student's reflections and qualities of his or her studies. A portfolio can result in a collection of different sizes of evidence of achievement ${ }^{5}$. Traditionally, a portfolio has been an aesthetic compilation of reports used for presentation, but recently this term has included the collection, management, and introduction of more significant material differences for use in an ever-expanding portfolio of works. Therefore, the introduction of portfolios into the health profession, especially as a learning and assessment tool, is recent but very fast, and portfolios are now often used in undergraduate (Davis, Ponnamperuma, and Ker, 2009; Rees and Sheard, 2004)' postgraduate (Tate et al. 1999) and continuing education (Burch \& Seggie, 2008) levels.

Portfolio prepared by a student either at the top of the workforce or formulated in an interesting way by the students. In addition, it may contain reports of grades, evaluations and tests, and it is a rule gathered in a suitable binder or IT framework so that it can be effectively disseminated to employees who are presented for specific valuation reasons. If a portfolio contains a collection of evidence, it is little more than a logbook of learning encounters. Learners, depending on their intelligence capacity, can reflect on learning encounters at three different cognitive levels: graphic, explanatory and evaluative (Al-Shehri, A., 1995).

Bangladesh Journal of Medical Education 2022; 13(1); Paul et al., publisher and licensee Association for Medical Education. This is an Open Access article which permits unrestricted non-commercial use, provided the original work is properly cited. 
In 2009, BSMMU introduced its competency-based residency program emphasis on integration and contextualizing within the educational modules. A good learning environment is fostered to ensure residents learning opportunities. The evaluation for certification of MD/MS degree of the university will be comprehensive, coordinated and phase cantered endeavouring to distinguish qualities anticipated of specialists for independent practice and lifelong learning. Evaluation might incorporate both formative evaluation and summative evaluation. Formative appraisal conducted all through the preparing stages by continuous developmental assessment, periodic formative assessment and end of block assessment (EBA). Components of EBA are clinical including long and short case and structured clinical assessment (SCA), medical record review, and logbook and portfolio assessment.

In 2007 a systematic review gave much valuable data for medical schools that are undertaking to implement a portfolio but other questions about portfolio implementation and utilization remain unanswered. As a result of a variety of engagements, the success of portfolio execution and utilization is highly variable. Recent orderly surveys of the factors which increase success of a portfolio incorporate: an appropriate presentation and mentoring; integration inside context and strategies; provision of data to students and instructors; provision of clear rules that don't diminish students' opportunity; user-friendliness that incorporates restricted time demands on students and tutors (Driessen, et al. 2007).
Within the early 1990s, the portfolio has used as elective assessment tools and since their introduction of por into medical education, portfolios have been the subject of educational investigations. The evidence to date recommends that their introduction has met with blended success (Dornan, Carroll, \& Parboosingh. 2002; Finlay, Maughan, \& Webster., 1998; Gordon, 2003). The aim of this study was to explore the present status of portfolio-based training and assessment in postgraduate residency program in competency-based post graduate training institute in Bangabandhu Sheikh Mujib Medical University (BSMMU).

\section{Methodology:}

The study was a descriptive cross-sectional for 1 (one) year and carried out in 4 clinical faculties (Medicine, Surgery, Paediatrics and Dental) in BSMMU with approval from ethical committee of Centre for Medical Education (CME). The study participants were selected from according to the following criteria across the BSMMU postgraduate residency training program: faculty member who had been responsible for training of the postgraduate residents in a BSMMU residency program and postgraduate residents who were enrolled with the BSMMU residency training program, and experiencing training for one year or more. Total of 294 participants were included, out of them 264 were residents, and 30 were faculty members. This was done by personally contacting every resident who was using the portfolio. All faculty members were invited by e-mail to participate. The wholehearted cooperation of the participants was solicited to conduct the study.

Bangladesh Journal of Medical Education 2022; 13(1); Paul et al., publisher and licensee Association for Medical Education. This is an Open Access article which permits unrestricted non-commercial use, provided the original work is properly cited. 
Table 1: Summary of the methods, respondents, objectives addressed

\begin{tabular}{|l|l|l|}
\hline \multicolumn{1}{|c|}{ Methods } & \multicolumn{1}{c|}{ Source } & \multicolumn{1}{c|}{ Objective addressed } \\
\hline $\begin{array}{l}\text { Quantitative data } \\
\text { (self-administered } \\
\text { questionnaire) }\end{array}$ & $\begin{array}{l}\text { Residents }(\mathrm{n}=264) \\
\text { Faculty }(\mathrm{n}=30)\end{array}$ & $\begin{array}{l}\text { To explore the opinion of residents and faculty } \\
\text { members regarding portfolio-based training and } \\
\text { assessment }\end{array}$ \\
\hline $\begin{array}{l}\text { Quantitative data } \\
\text { (Check list) }\end{array}$ & $\begin{array}{l}\text { Portfolio of } \\
\text { Residents }(\mathrm{N}=33)\end{array}$ & $\begin{array}{l}\text { To review the documents in relation to the portfolio, } \\
\text { maintained by residents in BSMMU. }\end{array}$ \\
\hline
\end{tabular}

Two semi structured questionnaires (one for the faculty members and one for the residents), and a checklist were developed with review of literature Challis M. 1999; Davis, Ponnamperuma, \& Ker, 2009; Jenkins, Mash, \& Derese, 2013) to achieve the study objectives. The semi structured questionnaire consisted of 29 statements, in that the key sections included: characteristics of portfolio; ownership and motivation to use the portfolio; faculty members and resident's commitment; and assessment issues. The statements were scored on a five point (1 to 5) Likert scale, ranging from "strongly disagree" to "strongly agree". The checklist was used for reviewing portfolios that were prepared by residents in the residency programme. The checklist was covered material in a portfolio based on two predominant issues: layout of the portfolio; content of the portfolio.

Layout of the portfolio included variables size and shape of the portfolio; type of the portfolio; presence of given instruction about maintaining the portfolio; and presence of written purpose instruction

Results:

A total of 264 residents (response rate $81 \%$ ) and 30 faculty members (response rate $55.6 \%$ ) responded, who were distributed across 4 (four) faculties in the BSMMU. Among all respondents most were male (68.6\% of residents and $93.3 \%$ of faculty Bangladesh Journal of Medical Education 2022; 13(1); Paul et al., publisher and licensee Association for Medical Education. This is an Open Access article which permits unrestricted non-commercial use, provided the original work is properly cited. about maintaining the portfolio which had been measured.

The variables that measured in content of the portfolio integrated personal information, learning plans, log book, problem-orientated clinical care, ethical reasoning and medico-legal issues, appraisal of a journal article), quality improvement cycle / audit, evidence of learning (e.g videotape or audiotape, discipline-specific certificates, certificates of congresses, seminars and workshops attended, listing of presentations and publications, activities of extra-curricular professional, use of the internet, referral notes and discharge summary.

\section{Data management:}

After validation, editing, coding, and entering of data in SPSS, the data were ready for analysis. Descriptive data were measured by mean, standard deviation and for showing comparison between residents and faculty members; t-test was used for continuous variables. A p-value of less than 0.05 was considered to be statistically significant.

members). From the faculty of medicine, about $55 \%$ of residents $(51.9 \%)$ and faculty members $(56.7 \%)$ responded in this study. More than $50 \%$ of the residents had in 2016 $(27.3 \%)$ and 2017 (25.4\%) sessions of academic training. evidence- based medicine (e.g. critical 
Figure-1 shows the residents views on layout of the portfolio $(n=25)$ about $60 \%$ of them have given a positive view on presence of instruction and purpose about maintaining the portfolio. While portfolios

\section{Presence of given instruction about maintaining the portfolio. $(n=25)$}

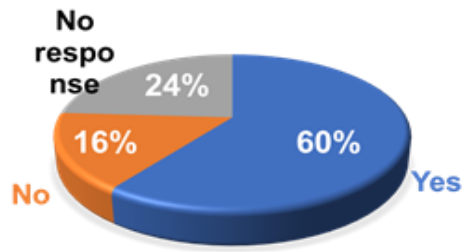

$(n=8)$ reviewed by researcher, there was absence of given instruction and written purpose about maintaining the portfolio. It was found that the portfolio incorporated 30 to 150 pages with various documents

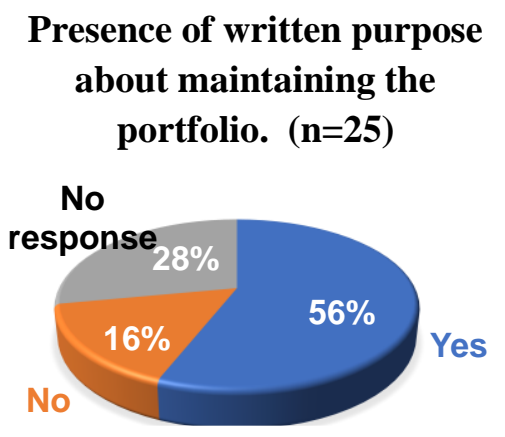

Figure 1: Distribution of residents views on layout of the portfolio.

Figure 2 deais viun icsiuuns (nresearcher $(n=8)$ views on content of the portfolio $(\mathrm{N}=33)$ Almost all of the residents stored personal information, log book, problem-orientated medical record, and about $80 \%$ of residents preserved discharge summary, referral note and learning plan. The residents (50\%) have stored medico-legal issues (death certificate). But there is poor maintenance of quality improvement cycle / audit (44\%) and discipline-specific certificates (40\%). (Figure 2)

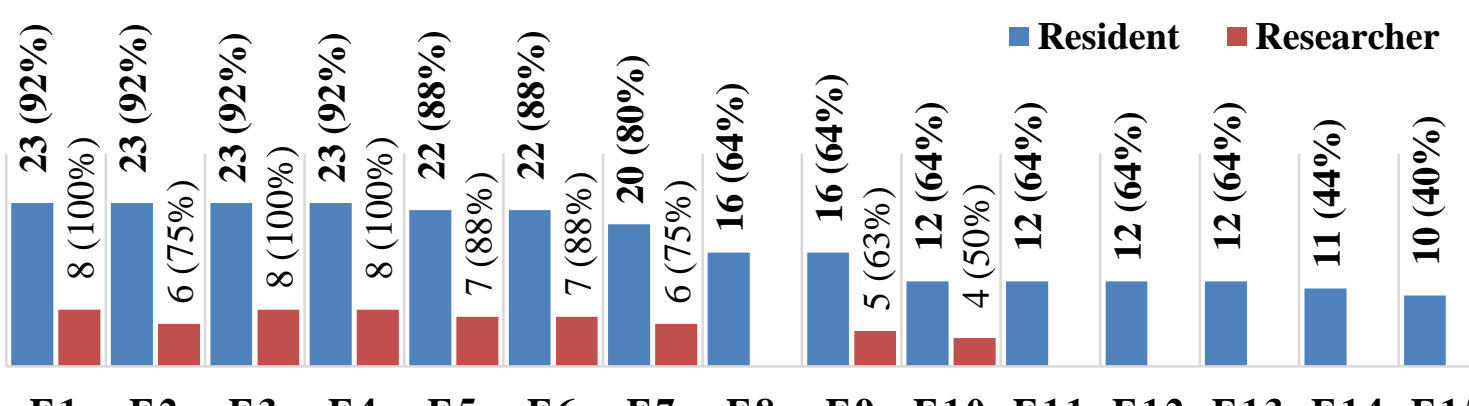
E 1
E2 E3 E4
E5 E6
E7 E8
E9 E10 E11 E12 E13 E14 E1:

Figure 2: Distribution of respondents views on content of the portfolio.

\begin{tabular}{|l|l|l|l|}
\hline E1 & Personal information & E9 & Evidence- based Medicine \\
\hline E2 & Learning plans & E10 & Medico legal Issues \\
\hline E3 & Log book & E11 & Evidence of learning (e.g video or audio) \\
\hline E4 & Problem-orientated medical record & E12 & Activities of Extra-curricular professional \\
\hline E5 & List of presentations & E13 & Record of use of the internet \\
\hline E6 & Discharge summary & E14 & Quality improvement cycle / audit \\
\hline E7 & Referral note & E15 & Discipline-specific certificates \\
\hline E8 & Certificates of Congresses, seminars and workshops attended \\
\hline
\end{tabular}

Bangladesh Journal of Medical Education 2022; 13(1); Paul et al., publisher and licensee Association for Medical Education. This is an Open Access article which permits unrestricted non-commercial use, provided the original work is properly cited. 
Regarding ten statements of characteristics of portfolio, residents have expressed very positive opinion to all statements reflected by mean score from $3.51 \pm 1.147$ to $3.85 \pm 1.056$ and faculty members were very positive to eight indicators among all statements $(3.57 \pm 0.774$ to 4.40 \pm 0.894$)$. Regarding opinions of respondents on characteristics of portfolio, both of the respondents perceived high satisfaction on portfolio based learning, reasonable contents, and practicable and feasible use of portfolio $(\mathrm{p}<0.05)$ except regular updating $(p<0.05)$ and comprehensiveness of portfolio. (Table 2).

Table 2: Distribution of respondents views on characteristics of the portfolio.

\begin{tabular}{|c|l|}
\hline \multicolumn{2}{|c|}{ Characteristics of the portfolio } \\
\hline A1 & $\begin{array}{l}\text { In order to enter the Phase-A examination } \\
\text { (after } 2 \text { years of training), a portfolio summary } \\
\text { is submitted, which forms part of a summative } \\
\text { assessment process. }\end{array}$ \\
\hline A2 & $\begin{array}{l}\text { This portfolio summary is supported by a } \\
\text { more comprehensive and extensive portfolio. }\end{array}$ \\
\hline A3 & $\begin{array}{l}\text { This portfolio summary is meticulously } \\
\text { updated by the residents and regularly } \\
\text { engaged with by their supervisors in a } \\
\text { formative assessment process. }\end{array}$ \\
\hline A4 & $\begin{array}{l}\text { The portfolio is not merely a logbook of work } \\
\text { done / activities. It also demonstrates insight } \\
\text { and reflective learning. }\end{array}$ \\
\hline A5 & $\begin{array}{l}\text { The process of portfolio is stimulating and } \\
\text { engaging, part of a life-long learning journey. }\end{array}$ \\
\hline A6 & $\begin{array}{l}\text { The process of portfolio is teaching the } \\
\text { residents to become a reflective practitioner. }\end{array}$ \\
\hline A7 & $\begin{array}{l}\text { It changes clinical practice/behaviour, improve } \\
\text { care for people in communities, and develop } \\
\text { the doctor into a mentor him/herself. }\end{array}$ \\
\hline A8 & $\begin{array}{l}\text { It is simple, user - friendly, and strives towards } \\
\text { less paperwork rather than more. }\end{array}$ \\
\hline A9 & Portfolio is practical and feasible to complete. \\
\hline A10 & What is required in portfolio are reasonable. \\
\hline
\end{tabular}

According to respondents' views on ownership and motivation to use the portfolio, five statements have been evaluated and reflected by mean score from 2.89 to 4.03 . View of the

\begin{tabular}{|c|c|c|c|}
\hline SI & $\begin{array}{c}\text { Faculty } \\
\text { No }\end{array}$ & $\begin{array}{c}\text { Mean } \pm \text { SD } \\
\text { Meandent }\end{array}$ & \multicolumn{1}{|c|}{$\begin{array}{c}\text { P- } \\
\text { value }\end{array}$} \\
\hline A1 & $4.40 \pm 0.894$ & $3.85 \pm 1.056$ & $0.003^{\mathrm{S}}$ \\
\hline A2 & $3.37 \pm 0.999$ & $3.64 \pm 1.035$ & $0.162^{\mathrm{S}}$ \\
\hline A3 & $3.17 \pm 1.053$ & $3.68 \pm 0.974$ & $0.016^{\mathrm{S}}$ \\
\hline A4 & $3.80 \pm 1.095$ & $3.84 \pm 0.957$ & 0.862 \\
\hline A5 & $3.90 \pm 1.062$ & $3.78 \pm 0.949$ & 0.548 \\
\hline A6 & $3.57 \pm 0.774$ & $3.82 \pm 0.926$ & 0.101 \\
\hline A7 & $3.90 \pm 0.923$ & $3.76 \pm 0.923$ & 0.423 \\
\hline A8 & $3.77 \pm 1.040$ & $3.51 \pm 1.147$ & 0.146 \\
\hline A9 & $4.23 \pm 0.817$ & $3.74 \pm 0.851$ & $0.003^{\mathrm{S}}$ \\
\hline A10 & $4.00 \pm 1.050$ & $3.82 \pm 0.829$ & 0.371 \\
\hline
\end{tabular}

both respondents is statistically significant $(\mathrm{p}<0.05)$ above mentioned statements except the portfolio makes my/them learning needs clearer. (Figure 3)

\begin{tabular}{|c|c|}
\hline \multicolumn{2}{|r|}{$\begin{array}{l}\text { Ownership and motivation to use the } \\
\text { portfolio }\end{array}$} \\
\hline B1 & $\begin{array}{l}\text { They/l only complete the portfolio } \\
\text { because it is a requirement of the } \\
\text { university. (260) }\end{array}$ \\
\hline B2 & $\begin{array}{l}\text { They/l complete the portfolio because } \\
\text { it helps me/them reflect on what I/they } \\
\text { have learnt. (261) }\end{array}$ \\
\hline B3 & $\begin{array}{l}\text { They/l complete the portfolio because } \\
\text { it makes my/them learning needs } \\
\text { clearer. }(260)\end{array}$ \\
\hline B4 & $\begin{array}{l}\text { They/l usually only work on the } \\
\text { portfolio when there is a university } \\
\text { deadline. (258) }\end{array}$ \\
\hline B5 & $\begin{array}{l}\text { The residents should take } \\
\text { responsibility for ensuring that his/her } \\
\text { learning events are observed and } \\
\text { captured in the portfolio. (257) }\end{array}$ \\
\hline
\end{tabular}

Figure 3: Distribution of respondent's views on ownership and motivation to use the portfolio

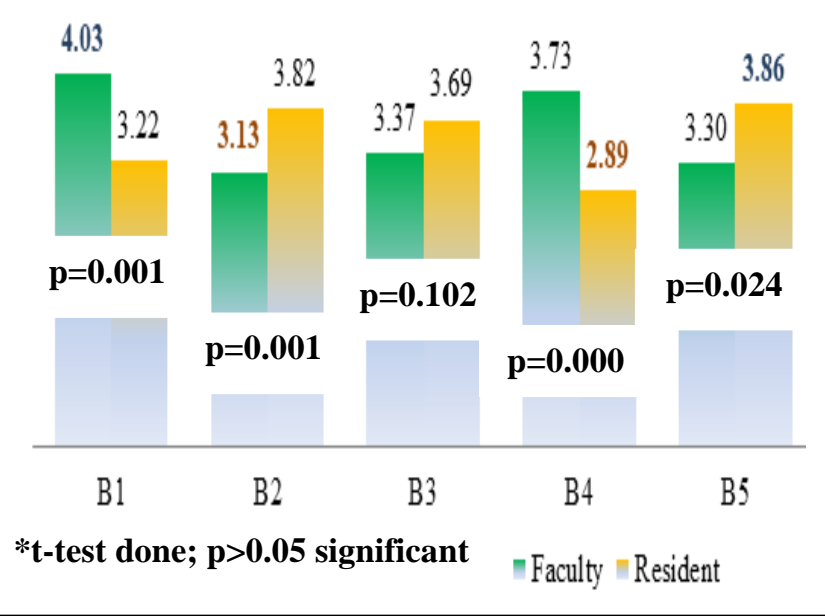

Regarding commitment of residents and course supervisors to use the portfolio, six statements have been evaluated (Figure 4) and both respondents showed moderate to high

Bangladesh Journal of Medical Education 2022; 13(1); Paul et al., publisher and licensee Association for Medical Education. This is an Open Access article which permits unrestricted non-commercial use, provided the original work is properly cited. 
satisfaction to four statements. While faculty members (3.13) have expressed mild satisfaction on selection of course supervisor but residents (3.78) have shown very positive opinion ( $p>0.001$ ). Also, faculty members and residents respondents have shown the lowest view on giving feedback on the supervision process (3.13 vs 3.07). (Figure 4)
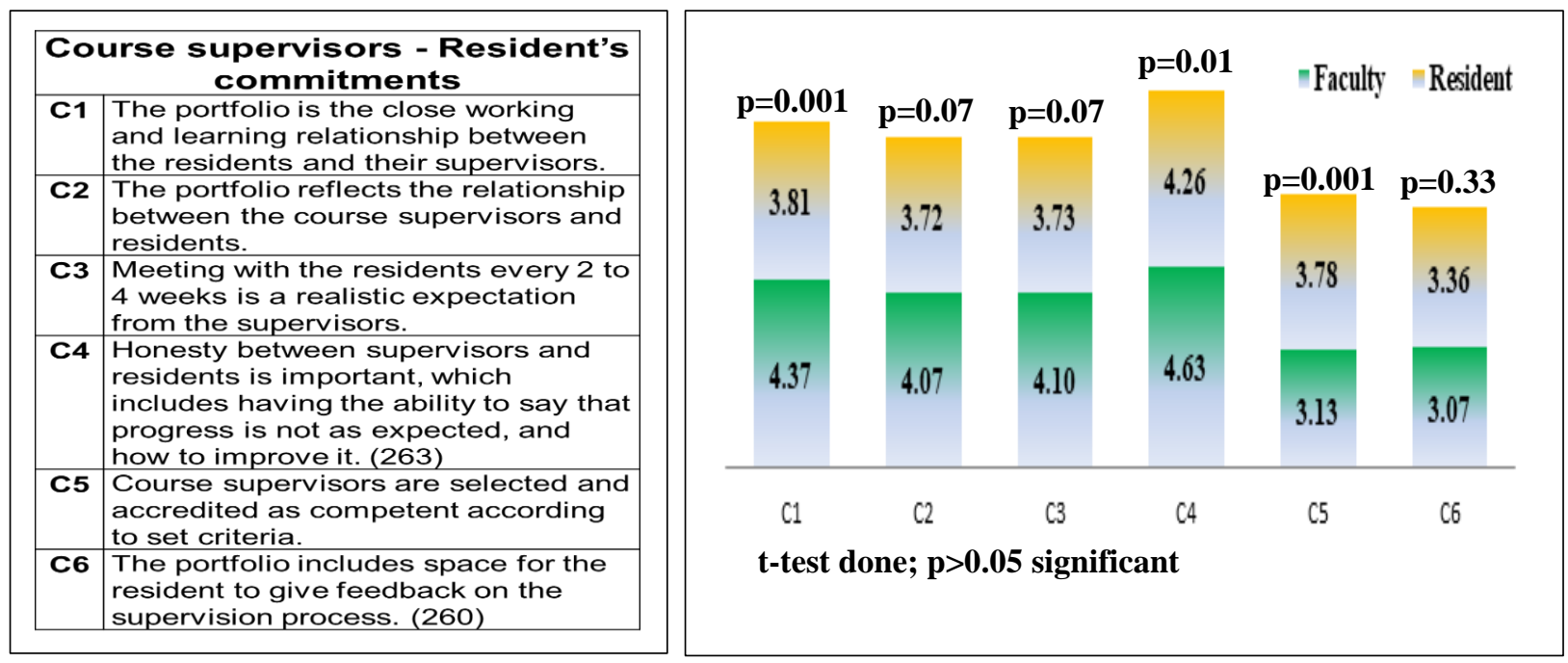

Figure 4: Distribution of respondents views on commitments to use the portfolio

Table 2 shows respondent's views on assessment of the portfolio, eight statements have been evaluated. Residents are very positive (>3.5) to five statements and faculty members are to 4 statements out of all indicator. Overall view of the respondents have expressed poor to moderate view and faculty members have less satisfied than residents.

Table 2: Distribution of respondents views on assessment issue of the portfolio

\begin{tabular}{|l|c|c|c|}
\hline \multicolumn{1}{|c|}{ Assessment Issues } & Faculty (20) & Resident (264) & \multirow{2}{*}{ P-value } \\
\cline { 2 - 3 } & Mean \pm SD & Mean \pm SD & \\
\hline $\begin{array}{l}\text { Regular meetings with the supervisors are used to set a } \\
\text { learning agenda and evaluate progress so that poor } \\
\text { competency is detected quickly and early on. These } \\
\text { meetings are recorded in the portfolio. (263) }\end{array}$ & $2.77 \pm 1.382$ & $3.39 \pm 1.099$ & $0.023^{\mathrm{s}}$ \\
\hline $\begin{array}{l}\text { The portfolio contributes significantly towards the } \\
\text { formative assessment. (262) }\end{array}$ & $3.57 \pm 0.858$ & $3.55 \pm 0.956$ & 0.937 \\
\hline $\begin{array}{l}\text { Competencies are graded on a Likert-type scale 1 to } \\
\text { 10. (258) }\end{array}$ & $3.24 \pm 1.354$ & $3.50 \pm 0.958$ & 0.435 \\
\hline $\begin{array}{l}\text { The portfolio encourages feedback and reports not } \\
\text { only from doctors, but also from nurses, allied health } \\
\text { professionals, managers, and patients. (264) }\end{array}$ & $3.00 \pm 1.462$ & $2.88 \pm 1.142$ & 0.654 \\
\hline $\begin{array}{l}\text { An indication of progress is recorded at the end of } \\
\text { each rotation, as well as the end of each year. (262) }\end{array}$ & $3.90 \pm 1.125$ & $3.60 \pm 0.940$ & 0.173 \\
\hline This progress report is done by the residents. (259) & $2.37 \pm 0.964$ & $3.31 \pm 1.029$ & $0.001^{\mathrm{S}}$ \\
\hline $\begin{array}{l}\text { There is also being an overall report of progress by the } \\
\text { course supervisors. (262) }\end{array}$ & $4.23 \pm 0.626$ & $3.73 \pm 0.858$ & $0.001^{\mathrm{S}}$ \\
\hline $\begin{array}{l}\text { This report includes a form of Likert scale to grade the } \\
\text { overall progress, e.g. Not sufficient, Slow progress, } \\
\text { Quite acceptable, Very good, Excellent. (262) }\end{array}$ & $3.79 \pm 0.978$ & $3.72 \pm 0.890$ & 0.708 \\
\hline
\end{tabular}

Bangladesh Journal of Medical Education 2022; 13(1); Paul et al., publisher and licensee Association for Medical Education. This is an Open Access article which permits unrestricted non-commercial use, provided the original work is properly cited. 


\section{Discussion:}

Layout and content of the portfolio: More than half of the residents have agreed with the presence of given instruction and written purpose about maintaining the portfolio. Also they have faced difficulties in compiling the information necessary for their portfolios. Many studies reported problems related to the poor preparation and introduction of portfolios by the institution. This claimed either that the purpose of the portfolio was not clearly defined (Pearson \& Heywood. 2004) or that learners and teachers were poorly or insufficiently informed about the portfolio and what it entailed (Davis, Ponnamperuma, \& Ker, 2009; Kjaer, Maagaard, \& Wied., 2006).

Characteristics of portfolio: In this regard, faculty members conveyed a poor view on meticulously updating by the residents $(2.88 \pm 0.947)$ and they expressed mild satisfaction on comprehensiveness of portfolio summary $(3.13 \pm 0.947)$ out of ten statements. Additionally, all respondents have perceived high satisfaction (Mean >3.5) on portfolio based learning, reasonable contents and practicable and feasible to use in the portfolio. Some authors described that an effective portfolio had a clear but flexible structure, allowing learners opportunities to describe their own unique development ${ }^{20,21}$. Portfolios are valued more when given the freedom of learners to decide on content (Driessen et al. 2005; Grant, et al. 2007).

Ownership and motivation to use portfolio: In these aspects, faculty have perceived more positive views than residents and views of the both respondents are statistically significant ( $p>0.05)$. Faculty members have expressed maximum opinion on completion of the portfolio by residents as requirement of the university (4.33) and work on the portfolio during university deadline (3.92) and less agreed that portfolio helped residents to reflect on their learning (3.1) but residents did not agreed that they are worked on the portfolio during university deadline. A study in clinical contexts where the content of a portfolio was often highly prescribed, portfolios was experienced as bureaucratic instruments (Pearson \& Heywood. 2004).

\section{Commitment of residents and supervisors:}

In this regard, residents expressed moderate to high commitment (3.36 to 4.26) but faculty members showed high satisfaction in four statements (4.17 to 4.83 ) out of six statements. Both respondents have conveyed high expression on relationships between residents and supervisors including close working, honesty and regular meeting, but there is statistically significant opinion between them $(p<0.05)$. The impact of constructive interaction with a mentor or supervisor on portfolio use has been explored in a number of studies. In a qualitative study ${ }^{22}$ of portfolio use, reported that the portfolio was 'usually not adopted where there was no support from the trainer' or where tensions existed in the trainee/ trainer relationship (Snadden \& Thomas 1998). When evaluating a pilot portfolio for 92 GPs, authors reported that users with a supportive trainer more commonly used their portfolio for reflection on their practice (Pearson \& Heywood. 2004). Another small study of nursing students, portfolio users spontaneously developed collaborative learning strategies and gave each other support, apparently as a result of being involved in the portfolio process (Tiwari and Tang 2003).

Assessment of portfolio: Relating to assessment of portfolio, overall view of the respondents have expressed poor to moderate view and faculty members have less satisfaction than residents. Findings of the

Bangladesh Journal of Medical Education 2022; 13(1); Paul et al., publisher and licensee Association for Medical Education. This is an Open Access article which permits unrestricted non-commercial use, provided the original work is properly cited. 
study revealed that respondents were not satisfied with portfolio based assessment. These findings are similar to McMullan, Endacott, \& Gray et al. 2003 who concluded in their literature review that portfolios become assessment-led, resulting in a reduction in learning value with $56(71 \%)$ of portfolio users showing that GP trainees feared they would be less honest and avoid showing shortcomings.

\section{Conclusion:}

The portfolio for postgraduate medical training in Bangladesh faces the same challenges as medical education research reports from developed countries of the world. Though there are so many constraints such as the lack of clear purpose and instruction, poor understanding regarding ownership, assessment issues, and confusion about educational impact in future, the portfolio as a feasible and acceptable tool to training and assess clinical competence and clinical specialization.

\section{Recommendation:}

Bangladesh (especially BSMMU) has moved towards partially portfolio based training and evaluation in postgraduate medical education. Based on the findings of this study, the following recommendations are made: developing generic format of portfolio based training and assessment as per global standards considering Bangladesh context; all Stakeholders should be orientated at the beginning for utilizing portfolio; maintaining a strong formative assessment system through portfolio during and at the end of each block/phase placement; an electronic portfolio with access through mobile technology should be explored in future.

\section{References:}

1. Al-Shehri, A., (1995). Learning by reflection in general practice: a study report, Education for General Practice, 7, pp.237-48.

2. Burch, V.C., \& Seggie, J.L., (2008). Use of a structured interview to assess portfolio-based learning, Medical Education, 42, pp. 894-900

3. Challis M., (1999). AMEE Medical Education Guide No. 11 (revised): Portfolio-based learning and assessment in medical education. Medical Teacher, 21 (4): 370-386. 10.1080/01421599979310.

4. Davis MH, Ponnamperuma GG, and Ker JS, (2009) Student perceptions of a portfolio assessment process. Medical Education, 43 (1), 89-98.

5. Davis, M.H., Friedman, B.D.M., Harden, R.M., Howie, J., Ker, J., McGhee, C. et al., (2001). Portfolio assessment in medical students' final examinations. Medical Teacher, 23 (4), pp-357-366.

6. Dornan, T., Carroll, C. \& Parboosingh, J., (2002). An electronic learning portfolio for reflective continuing professional development. Medical Education, 36(8), 767-76.

7. Driessen, E., van Tartwijk, J., van der Vleuten, C., Wass, V., (2007). Portfolios in medical education: why do they meet with mixed success? A systematic review, Medical Education, 41(12), pp.1224-1233.

8. Driessen, E.W., van Tartwijk, J., Overeem, K., Vermunt, J.D., van der Vleuten, C.P., (2005). Conditions for successful reflective use of portfolios in undergraduate medical education, Medical Education, 39(12), pp-1230-5.

9. Finlay, I.G., Maughan, T.S., \& Webster, D.J., (1998). A randomized controlled study of portfolio learning in undergraduate cancer education. Medical Education, 32 (2), pp-172 176.

Bangladesh Journal of Medical Education 2022; 13(1); Paul et al., publisher and licensee Association for Medical Education. This is an Open Access article which permits unrestricted non-commercial use, provided the original work is properly cited. 
10. Gordon, J., (2003). Assessing students' personal and professional development using portfolios and interviews, Medical Education, 37 (4), pp-335340.

11. Grant A,J., Vermunt, J,D., Kinnersley, P., \& Houston, H., (2007). Exploring students' perceptions on the use of significant event analysis, as part of a portfolio assessment process in general practice, as a tool for learning how to use reflection in learning, BMC Medical Education; 7, 5. https://www.researchgate.net/publicati on/51380745

12. Harden, R.M., Crosby, J.R., and Davis, M.H., (1999). AMEE Medical Education Guide No. 14: An introduction to outcome-based education, Medical Teacher, 21 (1), pp. $7-14$.

13. Jenkins, L., Mash, B., Derese, A., (2013). The national portfolio for postgraduate family medicine training in South Africa: a descriptive study of acceptability, educational impact, and usefulness for assessment, BMC Medical Education, 13(1), p.101.

14. Kjaer, K,N., Maagaard, R., \& Wied, S., (2006). Using an online portfolio in postgraduate training, Medical Teacher, 28 (8), pp. 708-712. DOI: 10.1080/01421590601047672

15. Kolb DA, Boyatzis RE, and Mainemelis C., (2001). Experiential learning theory: Previous research and new directions. Perspectives on Thinking, Learning and Cognitive Styles, 1: 227-247.

16. McMullan M, Endacott R, Gray MA, Jasper M, Miller CM, Scholes J, et al., (2003). Portfolios and assessment of competence: a review of the literature. Journal of Advanced Nursing, 41(3):283-94. doi: 10.1046/j.13652648.2003.02528. x. PMID: 12581116.

17. Miller, G.E., (1990). The assessment of clinical skills/ competence/performance, Academic Medicine, 65(9), pp-63-67.

18. Pearson, D. J., \& Heywood, P., (2004). Portfolio use in general practice vocational training: A survey of GP registrars. Medical Education, 38(1), 87-95.

19. Rees, C., and Sheard, C., (2004). Undergraduate medical students' views about a reflective portfolio assessment of their communication skills, Medical Education, 38 (2), pp.125-128.

20. Snadden, D., and Thomas, M.L., (1998). Portfolio learning in general practice vocational training - does it work?, Medical Education, 32 (4), pp..401-6.

21. Taber S, Frank JR, Harris KA, Glasgow NJ, Iobst W, and Talbot M., (2010). Identifying the policy implications of competency-based education. Medical Teacher, 32 (8): 687-691.

22. Tate, P., Foulkes, J., Neighbour, R., Campion, P., and Field, S., (1999). Assessing Physicians' Interpersonal Skills via Videotaped Encounters: A New Approach for the Royal College of General Practitioners Membership Examination, Journal of Health Communication, 4 (2), 143-152.

23. Tiwari A., and Tang, C., (2003). From process to outcome: The effect of portfolio assessment on student learning, Nurse Education Today, 23 (4), pp.269-277.

Bangladesh Journal of Medical Education 2022; 13(1); Paul et al., publisher and licensee Association for Medical Education. This is an Open Access article which permits unrestricted non-commercial use, provided the original work is properly cited. 